НАУКОВИЙ ВІСНИК

Scientific messenger of Lviv National University of
Veterinary Medicine and Biotechnologies

110

(y)

RIES: VETERINARY SCIEN
Науковий вісник Дьвівського національного університету ветеринарної медицини та біотехнологій імені С.3. Гжицького. Серія: Ветеринарні науки

\author{
Scientific Messenger of Lviv National University \\ of Veterinary Medicine and Biotechnologies. \\ Series: Veterinary sciences
}

UDC 619:639.3.09:619:578.819

\title{
Pathomorphological and histochemical parameters in the internal organs of carp infested Cariophyllaeus brachycollis
}

\author{
O. V. Bozhyk, V. J. Bozhyk \\ Stepan Gzhytskyi National University of Veterinary Medicine and Biotechnologies Lviv, Ukraine
}

Article info

Received 11.10.2021

Received in revised form 11.11.2021

Accepted 12.11.2021

Stepan Gzhytskyi National University of Veterinary Medicine and Biotechnologies Lviv, Pekarska Str., 50, Lviv, 79010, Ukraine. Tel: +38-097-585-45-14 E-mail:vbr.bozyk@gmail.com
Bozhyk, O. V., \& Bozhyk, V. J. (2021). Pathomorphological and histochemical parameters in the internal organs of carp infested Cariophyllaeus brachycollis. Scientific Messenger of Lviv National University of Veterinary Medicine and Biotechnologies. Series: Veterinary sciences, 23(104), 90 95. doi: $10.32718 /$ nvlvet10415

Pathomorphological and morphohistochemical changes were performed in the intestine of carp at the location of cysts of Cariophyllaeus brachycollis and other organs that do not have direct contact, primarily such as liver, kidneys, spleen, heart. A pathological autopsy of intensively infected carp with C. brachicollis cystism showed a slightly enlarged clay-yellowish liver; the gallbladder is often overflowing with bile. The kidneys are in most cases flabby and surrounded by a jelly-like mass, the spleen is also partially enlarged, and its edges are rounded, indicating dystrophic changes in these organs. The results of morphohistochemical studies have shown that granular dystrophy is observed in carp cells during cariophilic invasion in liver parenchyma cells. The content of $\alpha$-amino acids and acid phosphatase activity in dystrophically altered hepatocytes increases significantly. The content of CHIC-positive substances increases in and around the veins and sinusoidal capillaries. These processes coincide with the destruction of individual liver beams. At a karyophilosis in kidneys of carp expansion of distal departments of tortuous tubules and a granular dystrophy is observed. In addition, a decrease in the content of neutral glycoproteins, alkaline phosphatase activity with a simultaneous increase in protein and acid phosphatase activity is observed in the brush border of nephrocytes. The appearance of pyroninophilic cells, decrease in the content of CHIC-positive substances, decrease in alkaline activity and increase in acid phosphatase activity were detected in the renal corpuscle. In the endothelium of blood vessels and capillaries, an increase in protein content, a decrease in alkaline phosphatase activity and an increase in acid phosphatase activity were found. Morphohistochemical studies in the capsule of the carp spleen indicate an increase in such indicators as pyroninophilia, CHIC-positive reaction, the presence of $\alpha$-amino acids, acid phosphatase activity and decreased alkaline phosphatase activity. At the same time in the walls of blood vessels, there is an increase in the CHIC reaction and $\alpha$-amino acids, a decrease in alkaline phosphatase, and an increase in acid phosphatase activity. Around the vessels in the reticular tissue of the spleen and between the cells of the pancreas significantly increases the accumulation of reticulocytes with increased acid phosphatase, bright pyroninophilic lymphocytes, and hemosiderocytes with an enhanced CHIC response. Morphohistochemical studies of the heart of fish are accompanied by dilation and overflow of blood cavities and vessels of the heart, small hemorrhages, and locally - pyknosis of muscle cell nuclei and granular dystrophy in the myocardium. At the same time in the endocardium - an increase in the number of lymphocytes and plasma cells with high content of DNA and RNA, as well as a marked increase in $\alpha$-amino acids in connective tissue elastic fibers and squamous epithelial cells of the atrial and ventricular epicardium, alkaline and acid phosphatase. The amount of CHIC-positive substances is reduced in the striated muscle cells of the myocardium and the walls of the blood vessels of the epicardium. Thus, morphological and histochemical studies indicate profound and local changes in karyophilosis in the intestines of carp. In organs that are not directly related to the invasive onset, moderate histopathological and histochemical changes are observed, indicating a moderate severity of functional impairment.

Key words: carp, S. brachycollis, pathomorphological, histochemical parameters, organs hepatopancreas, kidneys, spleen, heart. 


\title{
Патоморфологічні та гістохімічні показники у внутрішніх органах коропів інвазованих Cariophyllaeus brachycollis
}

\author{
О. В. Божик, В. Й. Божик
}

Львівський національний університет ветеринарної медицини та біотехнологій імені С. З. Гжицького, м. Львів, Україна

Проведено патоморфологічні та морфогістохімічні зміни в кишечнику коропа за місцем локалізаиї иистод Cariophyllaеиs brachycollis та інших органах, які не мають прямого контакту, насамперед таких, як печінка, нирки, селезінка, серие. При патологоанатомічному розтині інтенсивно заражених коропів ицстодою C. brachicollis спостерігали деще збільшену в об'ємі печінку, глинисто-жовтуватого кольору; жовчний міхур часто переповнений жовчю. Нирки в більшості випадків в 'ялі й оточені студневидною масою, селезінка також частково збільшена в об'ємі, а краї ї̈ заокруглені, щзо свідчить про дистрофічні зміни в изи органах. Результати морфогістохімічних досліджень показали, що при інвазії каріофілідами в клітинах паренхіми печінки у коропів спостерігається зерниста дистрофія. У дистрофічно змінених гепатоцитах значно зростає вміст а-амінокислот і активність кислої фосфатази. У венах і синусоїних капілярах та навколо них наростає вміст ШИК-позитивних речовин. Ці проиеси збігаються з деструкиією окремих печінкових балок. При каріофільозі в нирках коропів спостерігається розширення дистальних відділів звивистих канальців і зерниста дистрофія. Поряд з цим в щітковій каймі нефрочитів спостерігається зменшення вмісту нейтральних глікопротеїдів, активності лужної фосфатази з одночасним наростанням в ній білків і активності кислої фосфатази. В нирковому тільиі виявлено появу піронінофільних клітин, зменшення вмісту ШИК-позитивних речовин, зниження активності лужної та підвищення активності кислої фосфатази. В ендотелію судин і капілярів встановлено підвищення вмісту білка, зниження активності лужної фосфатази і підвищення активності кислої фосфатази. Морфогістохімічні дослідження в капсулі селезінки коропа вказують на наростання таких показників, як піронінофілія, ШИК-позитивна реакція, наявність $\alpha$-амінокислот, активність кислої фосфатази і зниження лужно-фосфатазної активності. Одночасно в стінках судин спостерігається підсилення ШИК-реакцї̈, та $\alpha$-амінокислот, зниження лужної фосфатази і наростання активності кислої фосфатази. Навколо судин в ретикулярній тканині селезінки і між клітинами підилункової залози значно зростає скопичення ретикулочитів з підвищеною кількістю кислої фосфатази, яскраво піронінофільних лімфочитів і гемосидерочитів з підсиленою ШИК-реакцією. Проведені морфогістохімічні дослідження серия риб супроводжуються розширенням і переповненням кров'ю порожнин $і$ судин серия, дрібними крововиливами, а локально - пікнозом ядер м'язових клітин $i$ зернистою дистрофією в міокарді. Водночас в ендокарді - наростанням кількості лімфочитів і плазматичних клітин з високим вмістом ДНК $i$ РНК, а також помітним підвищенням $\alpha$ амінокислот в сполучнотканинних еластичних волокнах $і$ клітинах плоского епітелію епікарда передсердя $i$ шлуночка, лужної $i$ кислої фосфатаз у форменних елементах крові. В поперечносмугастих м'язових клітинах міокарда і стінках кровоносних судин епікарда знижується кількість ШИК-позитивних речовин. Таким чином, морфологічні та гістохімічні дослідження вказують на глибокі й локальні зміни при каріофільозі в кишечнику коропів. В органах, які не мають безпосереднього зв'язку з інвазійним початком, спостерігаються помірні патогістологічні і гістохімічні зміни, що свідчить про середній ступінь тяжккості функціональних порушень.

Ключові слова: короп, C. brachycollis, патоморфологічні, гістохімічні показники, органи - гепатопанкреас, нирки, селезінка, серие.

\section{Вступ}

Рибництво як одна $з$ галузей народного господарства України при значних водних площах має велике значення в збільшенні продукції харчування (Burgaz et al., 2019; Dobrianska et al., 2021; Hryhorenko et al., 2021). Проте успішному розвитку цієї галузі серйозних збитків завдають гельмінтозні захворювання риб, серед яких часто реєструються цистодози, в тому числі й каріофільоз коропів, внаслідок якого хвора риба погано росте, відстає в розвитку та дає продукцію низької якості, а часто й гине (Fedorovych \& Gutyj, 2019).

Вирішення проблеми боротьби і профілактики гельмінтозів риб здійснюється на основі комплексного використання біологічних, фізіологічних та іхтіологічних методів (Bauer et al., 1979; Vasil'kov \& Muzykovskij, 1979; Kofonov et al., 2020). Одночасно гістологічні та гістохімічні методи досліджень не отримали ще широкого застосування в наукових дослідженнях щодо патології риб, в тому числі й цистодозах. Наявні нечисленні дані стосовно патології риб при дії деяких паразитів неповні та переважно стосуються не організму загалом, а окремих органів (Poddubnaja et al., 1986; Sekretarjuk, 1986; Rudenko et al., 2019).
Морфогістологічні і гістохімічні зміни в організмі риб при певних паразитозах, без сумніву, мають як практичне, так і теоретичне значення. Тому успішному вирішенню цього питання повинно сприяти поглиблене комплексне дослідження морфофункціональних взаємозв'язків в системі паразит-хазяїн з використанням морфологічних і гістохімічних методів досліджень (Davydov, 1981; Kuperman et al., 1985; Stybel \& Fedorovych, 2016; Fedorovych, 2017).

Глибоке вивчення морфофункціональних взаємозв'язків паразита і хазяїна має важливе значення для правильного з'ясування патогенетичних і патоморфологічних процесів, що протікають при паразитарних захворюваннях.

У зв'язку з важливістю патогістологічних і гістохімічних досліджень та їх недостатнім використанням в іхтіопатології була виконана робота щодо дослідження змін органів та тканин коропа, викликаних каріофілідами.

Поряд з рибоводно-технологічними, селекційними та організаційними заходами дані дослідження можуть послужити основою для розробки специфічної патогенетичної терапії та профілактики гельмінтозних захворювань, в тому числі й каріофільозу коропа 
(Vihman \& Kapustina, 1975; Loboiko \& Krushelnytska, 2016).

Тому метою роботи було комплексне 3'ясування особливостей морфофункціональних взаємовідношень в системі “паразит-хазяїн” між каріофілідами і коропом. Для цього вивчено патоморфологічні та гістохімічні зміни в кишечнику та органах коропа, які не мають безпосереднього зв'язку з каріофілідами.

\section{Матеріал і методи досліджень}

Як матеріал використані комплексні дослідження проведені, за період 2018-2021 років в рибних господарствах західного регіону України. Протягом періоду вирощування та утримання коропа у господарствах здійснено комплексні дослідження з питань епізоотології та біології розвитку каріофільзу сезонної та вікової динаміки зараженості коропів, впливу факторів середовища, а також самих цистод, на органи в яких вони локалізуються, та організм загалом.

Повний паразитологічний розтин проводили за загальноприйнятою методикою (Маркевич, 1951; Биховська-Павловська, 1969).

Загальну мікроморфологію вивчали після фарбування органів гематоксиліном Ерліха 3 доофарбуванням еозином, а також пікрофуксином - за ВанГізоном. Виявлення глюкозаміногліконів проводили альціановим синім за Стідменом; глікогену і глікопротеїдів ШИК-реакцією за Мак-Манусом; диференціацію глікопротеїдів і глюкозаміногліканів здійснювали за Gones - Reud. Використовували реакцію Фельгена на РНК і ДНК, а також сумарне зафарбовування на РНК і ДНК галоціаніном за методом Ейнарсона, $\alpha$-амінокислоти виявляли за методом Яшума та Ітчікава. Активність лужної і кислої гліцеромонофосфатаз - за Гоморі. Також проводили відповідні контролі гістохімічних реакцій.

Дослідження і мікрофотографування гістологічних препаратів проводили за допомогою універсального мікроскопа BIOLAR-1 та мікрофотонасадки ФМН-8.

\section{Результати та їх обговорення}

3 метою з'ясування деяких аспектів патогенної дії цистод C. brachicollis на організм коропів загалом, крім морфогістохімічних змін в кишечнику, де локазізуються каріофіліди, були проведені також дослідження й інших органів коропа.

Не менший теоретичний і практичний інтерес становить питання про вплив каріофільозної інвазії на інші органи, які не мають 3 нею прямого контакту в системі паразит-хазяїн, але зв'язані загальними метаболічними процесами в організмі останнього. Не можна стверджувати, що паразитуючі в кишечнику коропа каріофіліди не мають впливу на організм риби загалом. Наявність такого опосередкованого впливу підтверджується результатами патологоанатомічних і морфогістохімічних досліджень насамперед таких органів, як печінка, нирки, селезінка, серце.

При розтині черевної порожнини сильно заражених коропів відразу привертають увагу зміни в парен- хіматозних органах: печінка дещо збільшена, глинисто-жовтуватого кольору, жовчний міхур переважно переповнений жовчю, нирки в більшості випадків в'ялі й оточені студневидною масою, селезінка також частково збільшена в об'ємі, а краї ії заокруглені, що свідчить про дистрофічні зміни в цих органах.

Вищеописані патоморфологічні зміни в паренхіматозних органах коропа при каріофільозі були підтверджені проведеними нами морфогістохімічними дослідженнями.

При дослідженні гепатопанкреаса встановлено деякі морфологічні та гістохімічні зміни в інтенсивно заражених коропів. При фарбуванні гематоксилінеозином спостерігається деструкція окремих печінкових балок, а в цитоплазмі гепатопанкреаса - зерниста дистрофія. Центральні вени і синусоїдні капіляри місцями сильно розширені та переповнені кров'ю. Повнокрів'я спостерігається також в васкулярній системі гепатопанкреаса і в протоках підшлункової залози. В просвіті жовчних протоків виявляється вміст блідо-рожевого кольору, а в зірчастих клітинах - скопичення гранул гемосидерину.

Результати морфогістохімічних досліджень показали, що при інвазії каріофілідами в клітинах паренхіми печінки у коропів спостерігається зерниста дистрофія. У дистрофічно змінених гепатоцитах значно зростає вміст $\alpha$-амінокислот і активність кислої фосфатази. У розширених і переповнених кров’ю центральних венах і синусоїдних капілярах та навколо них наростає вміст ШИК-позитивних речовин.

Ці порушення розвиваються, можна припустити, під впливом самих паразитів та дії токсичних процесів запалення. Такі зміни поєднуються місцями 3 дескомпенсацією окремих печінкових клітин, що свідчить про порушення функції паренхіми печінки і обмінних процесів органа загалом.

Поряд 3 деструктивними змінами окремих печінкових балок в гепатопанкреасі спостерігаються компенсаторно-пристосувальні та відновні процеси. Вони характеризуються збільшенням ядер в окремих епітеліоцитах, появою двоядерних клітин з високим вмістом вуглеводів, РНК і ДНК. Вищевикладені зміни свідчать про порушення функції печінкових клітин та обмінних процесів загалом.

При гістологічному дослідженні тканин нирок за фарбування гематоксилін-еозином у здорових коропів спостерігається звуження просвітів дистальних відділів нефронів.

Проведені дослідження показали, що при каріофільозі в нирках коропів спостерігається розширення дистальних відділів звивистих канальців, а в їх епітелії - зерниста дистрофія. Місцями окремі, розширені дистальні відділи звивистих канальців заповнені базофільним вмістом темного кольору у вигляді грудочок і зерен, а також помітна поява вакуолей і жовтокоричневих включень в епітелії проксимальних відділів. Різною мірою виражені дистрофічні зміни нефроцитів, що супроводжувались зниженням РНК і ДНК. Поряд 3 цим в щітковій каймі нефроцитів спостерігається зменшення вмісту нейтральних глікопротеїдів, активності лужної фосфатази з одночасним наростан- 
ням в ній білків і активності кислої фосфатази. Згідно 3 даними Несвєтова А. М. відомо, що дифузія ферменту в цитоплазму є досить характерною ознакою дистрофічних процесів. При цьому існує пряма залежність інтенсивності реакції лужної і кислої фосфатази від ступеня вираженості дистрофічних процесів в нирках.

В нирковому тільці при каріофільозі виявлено появу піронінофільних клітин, зменшення вмісту ШИКпозитивних речовин, зниження активності лужної і підвищення активності кислої фосфатази. В ендотелію кровоносних судин і капілярів встановлено підвищений вміст білків, зниження активності лужної фосфатази і підвищення активності кислої фосфатази. Такі зміни з боку ниркових тілець вказують на порушення проникливості клубочкового фільтра. Виявлені морфогістохімічні зміни в дистальних і проксимальних відділах звивистих канальців, в нирковому тільці та васкулярній системі нирок свідчать про порушення екскреторної функції нирок коропів при ураженні їх каріофілідами.

У інтенсивно заражених коропів при патологоанатомічному розтині виявлено значно збільшену селезінку $з$ дещо овальними краями.

Гістологічні дослідження показали, що зовні селезінка оточена капсулою, яка складається 3 тонкої мезотеліальної оболонки і тонкої аргірофільної мембрани, без власних клітин. В тканину селезінки включені також ділянки підшлункової залози і ендокринні елементи острівців Лангерганса, розкидані по всій тканині селезінки. В синтиціально-ретикулярній тканині пульпи селезінки коропів кровоносні судини заповнені форменими елементами, переважно - еритроцитами. Ретикулярна сполучна тканина містить в значній кількості лімфоцити.

В селезінці коропів уражених каріофільозом зростає кількість ретикулярних клітин зі значним вмістом гемосидерину, що спостерігається при постановках гістологічних реакцій. В паренхімі селезінки виявляються глибки пігменту жовтого кольору.

Морфогістохімічні дослідження показали, що при каріофільозі в капсулі селезінки коропів проходить наростання таких показників, як піронінофілія, ШИКпозитивна реакція, наявність $\alpha$-амінокислот, активність кислої фосфатази і зниження лужно-фосфатазної активності. Одночасно реєструється розширення i кровонаповнення судин, що пронизують паренхіму цього органа. В стінках судин спостерігається підсилення ШИК-реакції, забарвлення на $\alpha$-амінокислоти, зниження активності лужної фосфатази і наростання активності кислої фосфатази. Навколо судин, розміщених в ретикулярній тканині селезінки і в проміжках між клітинами підшлункової залози, значно зростає скопичення ретикулоцитів 3 підвищеною кількістю кислої фосфатази, яскраво піронінофільних лімфоцитів і гемосидероцитів, в яких спостерігається підсилене ШИК-позитивне забарвлення. В багатьох ділянках паренхіми селезінки реєструється скопичення значної кількості пігментовмістимих клітин темножовтого забарвлення. Згідно з сучасними уявленнями Васильєва Н. В., Романенко В. Д., гіперпластичні процеси в ретикулярній тканині та високий вміст плазматичних клітин пов'язаний зі здійсненням імуногенезу. Всі вищеперераховані зміни дозволяють стверджувати про наявні функціональноморфологічні зміни в селезінці коропів при каріофільозі.

Іхтіопатологічним розтином видимих змін в серці коропа при каріофільозі не спостерігали.

На гістопрепаратах 3 серця контрольних коропів, при фарбуванні гематоксилін-еозином, спостерігається, що м'язова тканина в різних його відділах (шлуночок і передсердя) дещо по-іншому реагує на барвники: в шлуночку вона більш оксифільна, а в передсерді - базофільна.

В уражених каріофільозом коропів вищевказані тинкторіальні особливості м'язової тканини в шлуночку і передсерді не змінювались. Хоча проведені нами морфогістохімічні дослідження свідчать, що при каріофільозі зміни в серці риб проявляються розширенням і переповненням кров'ю порожнин і судин серця, дрібними крововиливами, а локально - пікнозом ядер м'язових клітин і різної інтенсивності зернистою дистрофією в міокарді. Поряд з цим в ендокарді спостерігається наростання кількості лімфоцитів і плазматичних клітин 3 високим вмістом ДНК і РНК, а також помітне підвищення $\alpha$-амінокислот в сполучнотканинних еластичних волокнах і клітинах плоского епітелію епікарда передсердя і шлуночка, лужної і кислої фосфатаз в форменних елементах крові, які переповнюють передсердя. В поперечносмугастих м'язових клітинах міокарда i стінках кровоносних судин епікарда частково знижується кількість ШИКпозитивних речовин. Шишков В. П., Налетова Н. А., вважають, що міокардіодистрофія має місце при низці інвазійних захворювань і виникає як наслідок паразитування цистодозів в організмі риби.

Таким чином, морфологічні і гістохімічні дослідження показали, що найбільш глибокі зміни при каріофільозі спостерігаються в кишечнику риб, де вони носять локальний характер. В органах, які не мають безпосереднього зв'язку 3 інвазійним початком, спостерігаються помірні патогістологічні та гістохімічні зміни, які свідчать про середній ступінь тяжкості функціональних порушень.

Це підтверджується також результатами гістохімічної реакції на кислу фосфатазу; активність ії в процесі паразитування зростає не тільки в тканинах кишечної стінки, а й у таких органах, як печінка, нирки, селезінка, серце. Відповідно підвищення активності кислої фосфатази є загальним симптомом токсичного впливу каріофільозу на організм коропа. Цілком можливо, що каріофільоз коропа супроводжується загальним ацидозом, у зв'язку з чим активність кислої фосфатази підвищується. Не менш інтенсивним є припущення про те, що в умовах каріофільозної інвазії виникає необхідність більш інтенсивного лізісу речовин, розщеплення яких здійснюється 3 допомогою кислої фосфатази.

Значне зниження в більшості досліджуваних органів і тканин глюкозаміногліканів при каріофільозі коропа можна розглядати як порушення синтезу ре- 
човин глюкозаміногліканної природи, що $\epsilon$, можливо, однією з причин зростання проникливості сполучнотканинних елементів і кровоносних судин, що призводить до деструктивних тканинних змін і пониження імунних реакцій коропа.

Проведеними дослідженнями встановлено, що патологічний процес завжди поширюється і на внутрішні органи. При цьому домінуючими є дистрофічні зміни і циркуляторні морфологічні зміни внутрішніх органів, обмежені в основному циркуляторними розладами і більш-менш вираженими дистрофічними процесами. Саме у зв'язку з вищеописаними патологічними змінами в організмі коропа пов'язано зменшення росту, ваги і вгодованості, що пригнічує загальний розвиток риб, чим спричиняється шкода ставовому рибництву.

Оскільки описані зміни носять характер локальної дистрофії, некробіозу і лише в окремих випадках некрозу, вчасно проведена дегельмінтизація може зняти інвазійний початок і сприяти виздоровленню риби, а в подальшому - відновленню іiї продуктивносTi.

\section{Висновки}

Таким чином, морфологічні та гістохімічні дослідження показали, що найбільш глибокі зміни при каріофільозі спостерігаються в передньому та середньому відділах кишечнику в місцях фіксації сколекса i тісного контакту стробіли каріофілід 3 кишечником риб, де вони носять локальний характер. Проявляються в порушенні з боку кровоносної системи (гіпермія і набряк) в локальній запальній реакції, а далі появі вогнищ некрозу з подальшою частковою або повною атрофією тканин слизової оболонки. Глибина патологічних змін в ділянці контакту каріофілід з кишечником хазяїна підтверджується скопиченням в цих зонах лізосом, підвищенням активності кислої фосфатази, а далі зниженням вмісту білків, вуглеводів і їхніх сполук (нуклеопротеїдів, глікопротеїдів, муцинів і мукополісахаридів), а також активності лужної фосфатази.

В паренхіматозних органах і серці, які не мають безпосереднього зв'язку з інвазійним початком, спостерігаються помірні морфофункціональні та гістохімічні зміни, що свідчать про середню ступінь тяжкості функціональних порушень та найбільш чітко виражені в печінці й нирках.

Перспективи подальших досліджень. За результатами роботи при вивчені основних питань біології і епізоотології каріофільозу, патологоанатомічних, гістологічних та гістохімічних змін в кишечнику й органах, які не мають прямого контакту з інвазійним початком, буде використано для остаточної діагностики, пошуку і розробки нових лікувальних форм препаратів при цистодозах риб. При цьому вивчення патогенезу, пошук механізмів дії антигельмінтиків при цистодозах та інших гельмінтозах риб необхідно буде проводити з врахуванням адгезії та метаболічних процесів за місцем локалізації паразитів та організму загалом. Розробляючи терапію цистодозів у риб, варто враховувати збалансованість кормових раціонів щодо цукрово-протеїнового співвідношення, для врівноваження ферментативного статусу, енергетичного обміну і пластичних процесів в організмі риб. На основі результатів роботи патогенетичні препарати (вітаміни, амінокислоти, макро- і мікроелементи) застосовувати сумісно 3 етіотропними препаратами під час проведення дегельмінтизації.

Відомості про конфлікт інтересів. Автори стверджують про відсутність конфлікту інтересів щодо їх вкладу та результатів досліджень.

\section{References}

Bauer, O. N., Musselius, V. A., \& Strelkov, Ju. A. (1979). Bolezni prudovyh ryb. M.: Leg. i pishh. prom-st' (in Russian).

Burgaz, M., Matvienko, T., Bezik, K., \& Soborova, O. (2019). The current state of fish market in Ukraine. Ukrainian Journal of Veterinary and Agricultural Sciences, 2(3), 6-10. doi: 10.32718/ujvas2-3.02.

Davydov, V. G. (1981). Sravnitel'naja morfofunkcional'naja harakteristika nekotoryh sistem organov cestod otrjada Pseudophyllidea: Avtoref. dis. ... kand. biol. nauk. L. (in Russian).

Dobrianska, O., Zhyla, M., Vishchur, O., Deren, O., \& Koryliak, M. (2021). Intestinal histostructure and immune protection activity of age $-1+$ carp after consumption of a prebiotic feed additive. Ukrainian Journal of Veterinary and Agricultural Sciences, 4(2), 3137. doi: 10.32718/ujvas4-2.06.

Fedorovych, O. (2017). Protein composition of blood serum of the same age grass carp affected by monogenea, before and after "Granulated brovermectin" and "Avesstim" use. Scientific Messenger of LNU of Veterinary Medicine and Biotechnologies. Series: Veterinary Sciences, 19(73), 131-135. doi: 10.15421/nvlvet7327.

Fedorovych, O. V., \& Gutyj, B. V. (2019). State of the organism of the same year scaly carp infected by Eudiplozoon nipponicum. Scientific Messenger of Lviv National University of Veterinary Medicine and Biotechnologies. Series: Veterinary sciences, 21(94), 146-151. doi: 10.32718/nvlvet9427.

Hryhorenko, T., Samchyshyna, L., Chuzhma, N., Bazaieva, A., Savenko, N., Oborsky, V., \& Mykhailenko, N. (2021). Assessment of ecological conditions for growing the market-size fish in the Kantivka fattening pond (Khmelnychchyna, Ukraine). Ukrainian Journal of Veterinary and Agricultural Sciences, 4(3), 33-41. doi: 10.32718/ujvas4-3.06.

Kofonov, K., Potrokhov, O., Hrynevych, N., Zinkovskyi, O., Khomiak, O., Dunaievska, O., Rud, O., Kutsocon, L., Chemerys, V., Gutyj, B., Fijalovych, L., Vavrysevych, J., Todoriuk, V., Leskiv, K., Husar, P., \& Khumynets, P. (2020). Changes in the biochemical status of common carp juveniles (Cyprinus carpio L.) exposed to ammonium chloride and potassium phosphate. Ukrainian Journal of Ecology, 10(4), 137-147. doi: 10.15421/2020_181.

Kuperman, B. I., Biserova, N. M., Davydov, V. G., \& Poddubnaja, L. G. (1985). Morfofunkcional'nye osno- 
vy adaptacii cestod $\mathrm{k}$ organizmu hozjaina. VIII Vses. soveshh. po parazitam i boleznjam ryb. L., Nauka, 7880 (in Russian).

Loboiko, Y. V., \& Krushelnytska, O. V. (2016). Content of lipid peroxidation products and of antioxidant enzymes activity in carp tissues under the lerneos invasion. Scientific Messenger of LNU of Veterinary Medicine and Biotechnologies. Series: Veterinary Sciences, 18(1), 90-95. URL: https://nvlvet.com.ua/index.php/journal/ article/view/50.

Poddubnaja, L.G., Davydov, V. G., \& Kuperman, B. I. (1986). Morfofunkcional'noe izuchenie nekotoryh predstavitelej cestod otrjada Caryophyllidea (Cestoda). Biologija i jekologija vodnyh organizmov. L.: Nauka, 208-217 (in Russian).

Rudenko, O. P., Paranjak, R. P., Kovalchuk, N. A., Kit, L. P., Hradovych, N. I., Gutyj, B. V., Kalyn, B. M., Sukhorska, O. P., Butsiak, A. A., Kropyvka, S. I., Petruniv, V. V., Kovalska, L. M. (2019). Influence of seasonal factors on carp fish immune reactivity. Ukrainian Journal of Ecology, 2019, 9(3), 168-173. URL: https://www.ujecology.com/articles/influence-ofseasonal-factors-on-carp-fish-immune-reactivity.pdf.

Sekretarjuk, K. V. (1986). Morfofunkcional'nye vzaimootnoshenija $\mathrm{v}$ sisteme parazit-hozjain pri botriocefal'oze i filometroidoze karpa: Avtoref. dis. ... d-ra biol. nauk. M. (in Russian).

Stybel, V. V., \& Fedorovych, O. V. (2016). Hematological parameters of the same age grass carp and silver carp infested by daktylogyrus and gyrodactylus. Scientific Messenger of LNU of Veterinary Medicine and Biotechnologies. Series: Veterinary Sciences, 18(1), 181-184. URL: https://nvlvet.com.ua/index.php/journal/article/view/69.

Vasil'kov, G. V., \& Muzykovskij, A. M. (1979). Mery bor'by s cestodozami ryb. M.: Kolos (in Russian).

Vihman, A. A., \& Kapustina, N. I. (1975). K izucheniju reaktivnosti karpa pri kavioze. Materialy VI Vsesojuz. soveshh. po boleznjam ryb. M., 18-25 (in Russian). 